\title{
The Drivers of the Life Satisfaction of Pro-environment and Non-pro-environment People
}

\author{
Orose Leelakulthanit ${ }^{1}$ \\ ${ }^{1}$ NIDA Business School, National Institute of Development Administration, Bangkapi, Bangkok, Thailand \\ Correspondence: Orose Leelakulthanit, NIDA Business School, National Institute of Development \\ Administration, 118 Seri Thai Road, Bangkapi, Bangkok 10240, Thailand. Tel: 66-2-727-3966. Fax: \\ 66-2-374-3282. E-mail: orose@nida.ac.th
}

Received: February 27, 2017

doi:10.5539/ass.v13n5p96
Accepted: March 29, $2017 \quad$ Online Published: April 19, 2017

URL: https://doi.org/10.5539/ass.v13n5p96

\begin{abstract}
Happiness or life satisfaction tends to be the ultimate goal of human beings. It is the intention of this study to investigate the factors influencing the life satisfaction of pro-environment and non-pro-environment people. The data were collected from interviews with 320 adults, who were equally divided into pro-environment and non-pro-environment adults of at least 18 years of age and that had come to the randomly-selected shopping centers in Bangkok. The life satisfaction of the people, regardless of their environmentally-friendly attitude, was assumed to be driven by the personal characteristics of optimism and internal locus of control, and the domains of life of family, personal health, self-actualization, and material possessions, as well as the altruistic and biospheric values of being nature lovers. The results from the t-test suggested that pro-environment people are likely to be more satisfied with their lives than non-pro-environment people. Moreover, the multiple regression analysis indicated that the life satisfaction of the pro-environment people was positively influenced by the biospheric value of being a nature lover, self-actualization, and age, and was negatively influenced by education. The pro-environment people that were never married were more satisfied with their lives than those that were married. Finally, the life satisfaction of the non-pro-environment people was positively triggered by the personal characteristics of optimism and having an internal locus of control, as well as the domain of life of personal health and age.
\end{abstract}

Keywords: life satisfaction, sustainability, nature lover, altruism, self-actualization, optimism

\section{Introduction}

The ultimate goal of human-beings is to experience the happiness or life satisfaction is of course one of the ultimate goals of humans, and being able to live in a good-quality environment is obviously another essential goal. Despite the perceived importance of these goals, however, striving toward a better environment and living with well-being are oftentimes viewed separately, and they are even at times seen to be conflicting, as being environmentally friendly can involve elements of effort and discomfort (De Young, 1990-1991; Lorenzoni et al., 2007). In the current literature, the question whether these goals are necessarily at odds has been raised. In fact, some have indicated that people that are environmentally friendly experience greater happiness in life and receive greater satisfaction with their lives (Kasser \& Sheldon, 2002; Brown \& Kasser, 2005; Xiao \& Li, 2011). This study, therefore, will first focus on whether people that are pro-environment will tend to be more satisfied with their lives than non-pro-environment people. Secondly, this study also will investigate whether there are any differences between the significant determinants of life satisfaction of pro-environment and non-pro-environment people. These determinants are assumed to be the following: the personal characteristic of being optimistic and having control over one's life, being satisfied with various aspects of one's life, including family, personal health, self-actualization, material possessions, and the values of altruism and being lovers of nature.

\section{Literature Review}

\subsection{Life Satisfaction}

There have been indications that being pro-ecological promotes, albeit indirectly, a state of psychological restoration (i.e., the recovery from psychological states of fatigue for example produced by stress) (Hartig et al., 
2001). One more positive consequence of being pro-environment is being happy or having a sense of personal well-being (Talbert, 2008). According to some experts, a society that practices sustainable behaviors should be a happy one, or at least it should be on the way for the individuals living it to achieve such a state (Gardner \& Prugh, 2008; Talbert, 2008). A few empirical studies have support this claim and have even suggested that having a positive attitude toward the environment may lead to increased well-being. For example, it was found that consuming in a pro-environmental way is related to a person's greater sense of well-being (Brown \& Kasser, 2005), to higher overall satisfaction with one's life (Xiao \& Li, 2011), and greater overall happiness (Kasser \& Sheldon, 2002). It is hypothesized in the present study then that pro-environment people will be more satisfied with their lives than non-pro-environment people.

\subsection{Personal Characteristics}

\subsubsection{Optimism}

Schweizer, Beck-Seyffer, and Schneider (1999) have observed that optimism can have an influence an individual's sense of well-being, and Strassle, McKee and Plant (1999) stated that optimism is positively correlated with "life satisfaction, positive physical and mental health, lower frequencies of mental disorders, and self-esteem" (p. 191). Further, Avia (1997) suggested that positive emotions are essential to one's overall well-being, and that being in a good mood and feeling optimistic and being satisfied with one's life are important aspects of a healthy personality. Continuing this line of thought, Marshall et al. (1992) reported that optimism can be strongly associated with positive affect, and Peterson (2000) suggested that optimism can be linked to being in a good mood. With respect to the psychological or mental benefits of optimism, optimism has been found to buffer the effects of the stress of daily life on a person's self-esteem and burnout among woman executives (Fry 1995). Thus, it is hypothesized here that optimism is positively related to one's life satisfaction, regardless of the individual is pro- or non-pro-environment.

\subsubsection{Internal Locus of Control}

A person's internal control has been linked to a variety of outcomes, among them the following: academic success (Gifford, Briceño-Perriott \& Mianzo, 2006), higher self-motivation and social maturity (Nelson \& Mathias, 1995), lower incidences of stress and depression (Garber \& Seligman, 1980), and a longer life span (Chipperfield, 1993). Further, the degree of a person's psychological and physical well-being has also been shown to be influenced by the person's perception of his or her control over his/her life (Brandstadter \& Renner, 1990). One of the main effects of what has been termed the locus of control on the person's personal sense of well-being lies in how it affects his or her strategies for coping (Brandtstadter \& Baltes-Gotz, 1990). It follows then that external locus of control can be correlated with higher levels of stress (Garber \& Seligman, 1980), and Grob (2000) noted that stress is often caused because an individual perceives the situation to be beyond his or her coping ability. In this sense, the continued perception of stress can have and is likely to have a negative effect on the person's sense of well-being. Someone that has an internal locus of control however, who feels that the situation is within his or her control, can find even a stressful situation stimulating (Owusu-Ansah, 2008) - it is a matter of the person's perception. It can be suggested then that individuals with an "external locus of control" are significantly less happy than people that place the locus of control within themselves; that is, they tend to take more responsibility for themselves and tend to more actively manipulate their environment, thus taking control of events and changing what they are unhappy with (Kulshresta \& Sen, 2006). In contrast, people that place the locus of control on an external element feel powerless in terms of being able to control what they feel are their successes or failures (Nielsen, 1987); thus, are unable to remove themselves from situations about which they are not happy (Kulshresta \& Sen, 2006). Thus, it is hypothesized here that having an internal locus of control is positively related to a person's life satisfaction, regardless of the pro-environmental condition.

\subsection{Domains of Life}

\subsubsection{Family}

Families are important to society and to the individuals of course that make up these families, and the importance of the family as an economic unit and in terms of enhancing the individual's development and well-being has also been well established (Alesina \& Giuliano, 2010; Bogenschneider et al., 2012). It is essential then that families provide the necessary support for the members' happiness (Adams et al., 1996; North et al., 2008), and families that function well are vital in ensuring the person's best performance and productivity, and this in turn will improve their well-being. Alesina and Giuliano (2010) analyzed World Values Survey data and reported that people are happier and more satisfied with their lives in countries where stronger family ties obtain; on the other hand, strong family ties suggests less market-related participation and generally lower incomes. Nevertheless, people generally can be seen to be happier if they have strong family ties as opposed to persons living in more 
affluent countries for example where the family ties are weaker. It is hypothesized here then that satisfaction with one's family life is positively correlated with life satisfaction regardless whether the individual is pro- or non-pro-environment.

\subsubsection{Personal Health}

Health has also been seen to be closely related to a person's satisfaction with his/her life (Hamashima, 1994; Stolar, MacEntee \& Hill, 1992; von Heideken Wagert et al., 2005; Xavier, Ferraz, Marc, Escosteguy, \& Moriguchi, 2003). It should be noted that the connection between health and personal satisfaction has appeared in a variety of studies, including those that focus on health measures based on the self-report of the person's health. Medically-based health measures, at least in terms of diagnoses and prescribed medications, however, have not been investigated as frequently as individuals' self-reports in these life satisfaction studies, and so it can be hypothesized that satisfaction with one's personal health is positively related to life satisfaction regardless whether the individual is pro- or non-pro-environment.

\subsubsection{Self-Actualization}

Maslow's hierarchy of needs suggests that human needs can be organized according to a pyramid model, where each step represents a grouping of needs, of which there are, according to Maslow, five types: physiological, safety, love/belonging, esteem, and self-actualization. Maslow (1943) suggested that a new (higher) need emerges when the previous one is fulfilled or is at least partially satisfied. In 1962, he expanded his theory and recognized the first four needs as deficiency needs (D-Needs) and the last need as one of "being" (B-Needs). As he explained, "D-Need gratifications come from the world outside the person, not from within." Opposed to these needs, B-Needs or self-actualization needs are related to one's purpose in life and to fulfill our potential, or in Maslow's words, "what a man can be, he must be" in terms of being happy. It is hypothesized then that self-actualization is positively related to life satisfaction regardless whether the individual is pro- or non-pro-environment.

\subsubsection{Material Possessions}

When examining the relationships between materialism and well-being, it should be borne in mind that different economic and cultural circumstances can influence the meaning of these terms (materialism and well-being), and they can be viewed in terms of "possessions" and "consumption". As argued by Delhey (2010, p.81) "happiness tends to be pretty materialist in poorer places and more postmaterialist in richer ones." In comparing the data from 48 countries, the author demonstrated that income and possessions are more important in terms of one's personal quality of life in poorer countries than they are in richer ones. In the case of Thailand, a developing country, it can be hypothesized that satisfaction with one's material possessions is positively related to life satisfaction regardless whether the individual is pro- or non-pro-environment.

\subsection{Values}

\subsubsection{Altruism}

Altruism can be defined as the behaviors that are aimed at helping others without egotistical or selfish intent (Snyder \& Lopez, 2002). Post (2005) carried out a review of the literature and found that altruism has a variety of benefits for health and these include increased physical health, longevity, life satisfaction and reduced mortality, and depression and anxiety. Post suggested that the reason why altruism and kindness can be seen as powerful is that they take the individual's focus off his or her personal problems, and this leads then to increased connectedness and social interaction and the result is positive emotions that can have a powerful effect on the person's psychology and physical constitution. Thus, it is hypothesized that altruism is positively related to life satisfaction regardless whether the individual is pro- or non-pro-environment.

\subsubsection{Nature Lover}

Additionally, individuals that feel a stronger connection with nature may try to find more opportunities to obtain psychological benefits from being with nature or from having "a biophilia perspective," as it is sometimes referred to, in order to experience the satisfaction of feeling connected with other living things. In support of this idea, being connected with nature can be seen to be positively associated with one's contact with nature (e.g., the amount of time spent outdoors) and his or her interaction with other living things (e.g., pet ownership; Nisbet et al., 2009). There is substantial evidence that indicates that exposure to nature leads to increased happiness (Berman et al., 2008, 2012; Mayer et al., 2009; Nisbet \& Zelenski, 2011; White et al., 2013), and so it is hypothesized here that being a nature lover is positively related to a person's life satisfaction regardless whether he or she is pro- or non-pro-environment. 


\section{Methodology}

\subsection{Sampling}

The questionnaire used in this study was first tested with 9 MBA students in order to achieve a preliminary understanding of the content, and this was followed by a pretest, where 6 eligible pro-environment adult respondents and 2 non-pro-environment ones were interviewed and were at least 18 years of age. The questionnaire was revised based on the feedback from the interviewees for regarding suitability and clarity, and then main study was carried out by interviewing 320 eligible shoppers, who were divided into two equal groups - those that were pro-environment and those that were non-pro-environment - at 16 randomly-selected shopping centers in Bangkok. The proportion of pro-environment people out of the number of respondents approached turned out to be 96 percent and the proportion of the non-pro-environment people was 93 percent. The response rate of pro-environment people was 79 percent whereas that of the non-pro-environment people was 82 percent.

\subsection{Respondents}

The respondents from the pro-environment group and non-pro-environment group were similar in terms of demographics, and were approximately equally distributed as to gender (Table 1). The mean age of both groups was approximately 33 years, and for both groups, the never married outnumbered the married. Most of the individuals in both groups were well educated, with approximately $70 \%$ having at least a college education. Further, most of the individuals in both of these groups were employed, and both groups were more or less equally split in terms of household income at 70,000 baht/month.

Table 1. Demographic profile of pro-environment people and non-pro-environment people

\begin{tabular}{|c|c|c|}
\hline & Pro-environment & Non-pro-environment \\
\hline \multicolumn{3}{|l|}{ Gender } \\
\hline Male & $49 \%$ & $43 \%$ \\
\hline Female & $51 \%$ & $57 \%$ \\
\hline \multicolumn{3}{|l|}{ Age } \\
\hline Mean (years) & 32 & 34 \\
\hline \multicolumn{3}{|l|}{ Marital Status } \\
\hline Married & $39 \%$ & $42 \%$ \\
\hline Never married & $58 \%$ & $51 \%$ \\
\hline Not married (i.e., widowed, divorced, separated) & $3 \%$ & $7 \%$ \\
\hline \multicolumn{3}{|l|}{ Education } \\
\hline Up to upper primary school & $1 \%$ & $9 \%$ \\
\hline Lower secondary school & $4 \%$ & $5 \%$ \\
\hline Upper secondary school & $9 \%$ & $8 \%$ \\
\hline Some college & $18 \%$ & $10 \%$ \\
\hline College graduate & $56 \%$ & $62 \%$ \\
\hline Advanced degree & $11 \%$ & $6 \%$ \\
\hline \multicolumn{3}{|l|}{ Employment Status } \\
\hline Employed & $80 \%$ & $77 \%$ \\
\hline Unemployed & $4 \%$ & $3 \%$ \\
\hline Not employed (i.e., retired, housewife, student) & $16 \%$ & $20 \%$ \\
\hline \multicolumn{3}{|l|}{ Monthly Household Income } \\
\hline Up to 39,999 & $24 \%$ & $25 \%$ \\
\hline $40,000-59,999$ & $20 \%$ & $21 \%$ \\
\hline $60,000-79,999$ & $19 \%$ & $18 \%$ \\
\hline $80,000-99,999$ & $16 \%$ & $15 \%$ \\
\hline 100,000 or more & $21 \%$ & $21 \%$ \\
\hline
\end{tabular}

\subsection{Measures}

The scale used to measure the individual's life satisfaction and satisfaction with the various aspects of his/her life, including family, personal health, and material possessions, was similar to the scale used in the study of Leelakulthanit, Day, and Walters (1991). Self-actualization was measured using a single-item seven-point scale, ranging from extremely satisfied to extremely dissatisfied; however, the items of optimism, internal locus of 
control, and altruism were multi-item measured using a modified seven-point Likert scale (from 1 equaling strongly agree to 7 equaling strongly disagree). The idea of a person being a nature lover was measured using multi-item seven-point scale ranging from 1 to 7 , referring from little to very much respectively.

\section{Data Analysis}

Exploratory factor analyses were used to attain the unidimensionality of each construct for the multi-item measures. If the unrotated factor analysis results indicated more than one factor, then the items that were weakly related to no factors (factor loadings $<.35$ ) or that clearly were connected with more than a single domain were dropped. The remaining items were refactored until unidimensionality was obtained. Then reliability analyses were conducted, as indicated by Cronbach alphas and the reliabilities that were obtained (in the .7 to .9 range) supported the use of the measures (Nunnally, 1978) and the reliabilities ranged from .76 to .96 (see Appendix A).

\section{Results}

As suggest by the t-test, the pro-environment people were more satisfied with their lives than the non-pro-environment people, and on the average life satisfaction scale of 7.5, the mean life satisfaction of the pro-environment group was 3.22, as opposed to that of the non-pro-environment group at 3.42 .

The impact of the personal characteristics of optimism, and internal locus of control, satisfaction with such areas of life as family, personal health, and self-actualization and material possessions, in addition to such values as altruism and being a nature lover and the demographic characteristics regarding life satisfaction, were investigated via multiple regression analyses for both groups (pro-environment and non-pro-environment). Additionally, the values obtained from the scale items (optimism, internal locus of control, the subdomains associated with a particular area of life and life satisfaction, as well as altruism and being a lover of nature) were averaged in order to create measures for those constructs. Education on the other hand was categorized into two groups: those with less than a bachelor degree and those with a bachelor degree or higher. Further, the individuals' household income was also divided into two groups by splitting the group according to monthly household income level at 70,000 baht (\$US $1=35$ Baht). For the pro-environment and non-pro-environment groups multiple regression analyses were carried out by regressing life satisfaction on optimism, internal locus of control, satisfaction with four domains of life - family, personal health, self, and material possessions - and the demographic characteristics of gender, age, marital status, education and monthly household income. These represented the control variables.

Table 2. Results of multiple regression of life satisfaction on its determinants in the pro-environment group

\begin{tabular}{|c|c|c|c|c|c|c|c|}
\hline \multirow{2}{*}{ Model } & \multicolumn{2}{|c|}{ Unstandardized Coefficients } & \multirow{2}{*}{$\begin{array}{c}\text { Standardized Coefficients } \\
\text { Beta }\end{array}$} & \multirow{2}{*}{$\mathrm{t}$} & \multirow{2}{*}{ Sig. } & \multicolumn{2}{|c|}{ Collinearity Statistics } \\
\hline & $\mathrm{B}$ & Std. Error & & & & Tolerance & VIF \\
\hline (Constant) & 2.265 & .725 & & 3.123 & .002 & & \\
\hline optimist & -.080 & .127 & -.061 & -.633 & .528 & .492 & 2.032 \\
\hline control & .123 & .159 & .068 & .778 & .438 & .591 & 1.691 \\
\hline fam & .045 & .114 & .033 & .393 & .695 & .632 & 1.582 \\
\hline phea & .067 & .083 & .071 & .806 & .422 & .597 & 1.676 \\
\hline self-actualization & .338 & .078 & .358 & 4.314 & $.000 * *$ & .666 & 1.501 \\
\hline mat & .124 & .127 & .091 & .978 & .330 & .531 & 1.882 \\
\hline altruism & -.115 & .100 & -.085 & -1.148 & .253 & .830 & 1.204 \\
\hline nuture & .252 & .066 & .282 & 3.791 & $.000 * *$ & .830 & 1.204 \\
\hline gender & -.033 & .137 & -.017 & -.244 & .807 & .935 & 1.069 \\
\hline age & -.022 & .010 & -.197 & -2.177 & $.031 *$ & .561 & 1.783 \\
\hline marygroup & -.401 & .187 & -.201 & -2.150 & $.033^{*}$ & .522 & 1.915 \\
\hline educgroup & .335 & .168 & .158 & 1.990 & $.049 *$ & .731 & 1.367 \\
\hline incgroup & -.171 & .156 & -.088 & -1.098 & .274 & .718 & 1.392 \\
\hline $\mathrm{R}^{2}=.30$ & $F_{13,146}=$ & $\mathrm{P}=.000$ & at $\alpha \leq .05$ & $=$ Signi & cant at & $\leq .01$ & \\
\hline
\end{tabular}

The results of the regression for the pro-environment group are shown in Table 2, suggesting that together the 13 independent variables made up $36 \%$ of the variance in life satisfaction $(\mathrm{R}$-square $=.36$ ). In addition, the items of being a nature lover, self-actualization, and age were seen to have a positive influence on life satisfaction. On the 
other hand, education had a negative effect on life satisfaction. This means that the more the people were found to be lovers of nature and the more satisfied they were with their self-actualization, in addition to being older, the more satisfied they tended to be with their lives. This is in contrast to education level, where it was seen that the greater their education level, the less satisfied they tended to be with their lives. Further, those that were never married tended to be more satisfied with their lives than those that had been. As the standardized beta coefficients indicated, the individual's satisfaction with his/her self-actualization had the greatest influence on his/her life satisfaction. This was followed by the values of being a nature lover, marital status, age, and education. It is important to point out here that multicollinearity was not a problem because the magnitude of the variance inflation factors that were connected with the independent variables was less than ten (Wetherill, Duncombe, Kenward, Köllerström, Paul \& Vowden, 1986).

For the non-pro-environment group, as shown in Table 3, the results of the regression indicated that taken together, the 13 independent variables explained $37 \%$ of the variance in life satisfaction (R-square $=.37$ ), and optimism, internal locus of control, and satisfaction with one's personal health and age were seen to have a positive influence on life satisfaction. In other words, the more optimistic a person was, the more he/she felt that he/she was in control of his/her life, and the more the individual was satisfied with his/her health and the older he/she was, the greater was the extent of his/her satisfaction. As can be seen from the standardized beta coefficients, the person's satisfaction with his/her personal health affected his/her life satisfaction the most, and this was followed by age, optimism, and internal locus of control. It should be pointed out that multicollinearity was again not seen to be a problem because the magnitude of the variance inflation factors related to the independent variables was less than ten (Wetherill, Duncombe, Kenward, Köllerström, Paul \& Vowden, 1986).

Table 3. Results of multiple regression of life satisfaction on its determinants in the non-pro-environment group

\begin{tabular}{|c|c|c|c|c|c|c|c|}
\hline \multirow{2}{*}{ Model } & \multicolumn{2}{|c|}{ Unstandardized Coefficients } & \multirow{2}{*}{$\frac{\text { Standardized Coefficients }}{\text { Beta }}$} & \multirow{2}{*}{$\mathrm{t}$} & \multirow{2}{*}{ Sig. } & \multicolumn{2}{|c|}{ Collinearity Statistics } \\
\hline & $\mathrm{B}$ & Std. Error & & & & Tolerance & VIF \\
\hline (Constant) & 2.310 & .787 & & 2.934 & .004 & & \\
\hline optimist & .276 & .108 & .252 & 2.551 & $.012 *$ & .491 & 2.035 \\
\hline control & .265 & .133 & .222 & 2.000 & .048 & .389 & 2.569 \\
\hline fam & -.078 & .097 & -.077 & -.800 & .425 & .515 & 1.943 \\
\hline phea & .262 & .076 & .295 & 3.438 & $.001 *$ & .651 & 1.535 \\
\hline self-actualization & -.069 & .082 & -.084 & -.849 & .398 & .490 & 2.042 \\
\hline mat & .092 & .102 & .093 & .901 & .369 & .445 & 2.246 \\
\hline altruism & -.033 & .091 & -.031 & -.365 & .716 & .654 & 1.530 \\
\hline nuture & .083 & .057 & .117 & 1.442 & .152 & .734 & 1.363 \\
\hline gender & .000 & .145 & .000 & .001 & .999 & .802 & 1.247 \\
\hline age & -.026 & .010 & -.278 & -2.751 & $.007 *$ & .471 & 2.125 \\
\hline marygroup & -.200 & .177 & -.108 & -1.127 & .262 & .522 & 1.917 \\
\hline educgroup & -.181 & .164 & -.090 & -1.109 & .270 & .724 & 1.382 \\
\hline incgroup & .030 & .146 & .016 & .207 & .836 & .772 & 1.295 \\
\hline
\end{tabular}

The mean values of the independent variables were determined, as shown in Table 4, so that the profile of the pro-environment and non-pro-environment people could be assessed, and it was found that the pro-environment people were the most altruistic and the least happy with their health. On the other hand, the non-pro-environment people were found to be the most altruistic but interestingly demonstrated the least love for nature. The pro-environment people overall showed themselves to be more optimistic and to have a greater locus of control regarding, and satisfaction with, the various domains of their life (family, personal health, self-actualization, and material possessions) and they were seen to be nature lovers and altruistic. The greatest difference in the mean values of the pro-environment people and non-pro-environment people was related to their being lovers of nature or not, and it became clear that the pro-environment people were greater lovers of nature than the non-pro-environment people. Finally, the least mean difference of the two groups was related to internal locus of control. 
Table 4. Mean Difference of Determinants of Life Satisfaction for the Pro-environment and Non-pro-environment Groups of Respondents

\begin{tabular}{cccccc}
\hline \multirow{2}{*}{$\begin{array}{c}\text { Determinant of Life } \\
\text { Satisfaction }\end{array}$} & \multicolumn{2}{c}{ Mean Score } & Mean & \multicolumn{2}{c}{$\mathrm{t}$ - test } \\
\cline { 2 - 3 } \cline { 5 - 6 } Pro-environment & Non- pro-environment & Difference & $\mathrm{t}$ - value & Significant \\
\hline optimist & 2.35 & 2.89 & -.54 & -5.71 & $0.00^{*}$ \\
control & 2.33 & 2.75 & -.43 & -5.29 & $0.00^{*}$ \\
fam & 2.47 & 3.20 & -.74 & -7.85 & $0.00^{*}$ \\
phea & 2.86 & 3.48 & -.62 & -5.14 & $0.00^{*}$ \\
self-actualization & 2.83 & 3.35 & -.52 & -4.22 & $0.00^{*}$ \\
mat & 2.68 & 3.36 & -.68 & -6.90 & $0.00^{*}$ \\
altruism & 2.03 & 2.65 & -.62 & -6.54 & $0.00^{*}$ \\
nature & 2.24 & 4.21 & -1.98 & -14.63 & $0.00^{*}$ \\
\hline
\end{tabular}

$*$ = Significant at $\alpha \leq .01$

\section{Discussion}

It has become clear that the value of being a nature lover was a differentiating factor for the pro-environment people and non-pro-environment people because pro-environment people tend to love nature much more than non-pro-environment people. Additionally, being a nature lover was also seen to be positively significantly related to life satisfaction only for the group of pro-environment individuals but was not significantly related to the life satisfaction of the non-pro-environment group. It follows that sustainability development should be promoted through creating the value of being a nature lover for the non-pro-environment group, especially youngsters, who will have more time dealing with the deteriorating environment that we are now facing. Nowadays, in the information technology era, people mostly spend their time in front of electronic screens, and this takes place of course for the most part indoor, thus leading to a situation in which people are alienated from nature. People can be "taken back" to nature through several means, for instance, adopting outdoor hobbies, and growing trees for example.

It is noteworthy that according to the mean value of altruism in the present study, both pro-environment and non-pro-environment people were seen to be altruistic rather than nature lovers, having internal locus of control, being optimist, and being satisfied with their domains of life, including family, material possessions, self-actualization, and personal health. However, it is a pity that the value of altruism did not appear to have any influence on the life satisfaction of either group. This may be because altruism tends to make life meaningful but it does not necessarily make us happy.

\section{Conclusion}

The personal characteristics of being optimist and having an internal locus of control tended to contribute positively to the life satisfaction of only the non-pro-environment people and did not influence the life satisfaction of pro-environment people. Satisfaction with the personal health domain of one's life had a positive impact on the life satisfaction of the non-pro-environment people, whereas satisfaction with self-actualization did so for the pro-environment people. Neither the value of altruism nor that of being a nature lover contributed to the life satisfaction of the non-pro-environment people, while the value of being a nature lover had a positive influence on the life satisfaction of the pro-environment people. Demographically, age had a positive impact on the life satisfaction of both the non-pro-environment and pro-environment group, whereas education had a negative influence on the life satisfaction of the pro-environment group. The individuals that were never married were found to be more satisfied with their life than those that were married for the pro-environment group.

\section{References}

Adams, G. A., King, L. A., \& King, D. W. (1996). Relationships of job and family involvement, family social support, and work-family conflict with job and life satisfaction. Journal of Applied Psychology, 81(4), 411-420. https://doi.org/10.1037/0021-9010.81.4.411

Alesina, A., \& Giuliano, P. (2010). The power of the family. Journal of Economic Growth, 15(2), 93-125. https://doi.org/10.1007/s10887-010-9052-z

Avia, M. D. (1997). Personality and positive outcomes. European Journal of Personality, 11(1), 33-56. https://doi.org/ 10.1002/(SICI)1099-0984(199703)11:1<33::AID-PER270>3.0.CO;2-L

Berman, M. G., Jonides, J., \& Kaplan, S. (2008). The cognitive benefits of interacting with nature. Psychological 
Science, 19(12), 1207-1212. https://doi.org/10.1111/j.1467-9280.2008.02225.x

Berman, M. G., Kross, E., Krpan, K. M., Askren, M. K., Burson, A., Deldin, P. J., ... Jonides, J. (2012). Interacting with nature improves cognition and affect for individuals with depression. Journal of Affective Disorders, 140(3), 300-305. https://doi.org/10.1016/j.jad.2012.03.012

Bogenschneider, K., Little, O. M., Ooms, T., Benning, S., Cadigan, K., \& Corbett, T. (2012). The family impact lens: A family-focused, evidence-informed approach to policy and practice. Family Relations, 61(3), 514 531. https://doi.org/10.1111/j.1741-3729.2012.00704.x

Brandtstädter, J. \& Baltes-Gotz, B. (1990). Personal control over development and quality of life perspectives in adulthood. In P. B. Baltes \& M. M. Baltes (Eds.), Successful aging: Perspectives from behavioral sciences (pp. 197-224). Cambridge, England: Cambridge University Press.

Brandtstädter, J., \& Renner, G. (1990). Tenacious goal pursuit and flexible goal adjustment: Explication and age-related analysis of assimilative and accommodative strategies of coping. Psychology and Aging, 5(1), 58-67. https://doi.org/10.1037/0882-7974.5.1.58

Brown, K. W., \& Kasser, T. (2005). Are psychological and ecological well-being compatible? The role of values, mindfulness, and lifestyle. Social Indicators Research, 74(2), 349-368. https://doi.org/10.1007/s11205-004-8207-8

Chipperfield, J. G. (1993). Perceived barriers in coping with health problems: A twelve-year longitudinal study of survival among elderly individuals. Journal of Aging and Health, 5(1), 123-139. https://doi.org/10.1177/089826439300500106

De Young, R. (1990). Some psychological aspects of living lightly: Desired lifestyle patterns and conservation behavior. Journal of Environmental Systems, 20(3), 215-227. https://doi.org/10.2190/030q-q4ke-7yfb-4q0f

Delhey, J. (2010). From materialist to post-materialist happiness? National affluence and determinants of life satisfaction in cross-national perspective. Social Indicators Research, 97(1), 65-84. https://doi.org/10.1007/s11205-009-9558-y

Fry, P. (1995). Perfectionism, humor, and optimism as moderators of health outcomes and determinants of coping styles of women executive. Genetic, Social \& General Psychology Monographs, 121(2), 213-245.

Garber, J. \& Seligman, M. E. P. (Eds.). (1980). Human helplessness: Theory and applications. New York: Academic Press.

Gardner, G. \& Prugh, T. (2008). Seeding the sustainable economy. In L. Starke (Ed.), State of the world 2008: Innovations for a sustainable economy (pp. 3-17, 213-216). New York: W. W. Norton.

Gifford, D., Briceño-Perriott, J., \& Mianzo, F. (2006). Locus of control: Academic achievement and retention in a sample of university first-year students. Journal of College Admission, (191), 18-25.

Grob, A. (2000). Perceived control and subjective well-being across nations and across the life span. In E. Diener \& E. M. Suh (Eds.), Culture and subjective well-being (pp. 319-339). Cambridge, MA: MIT Press.

Hamashima, C. (1994). The quality of life in aged people. Japanese Journal of Hygiene, 49(2), 533-542.

Hartig, T., Kaiser, F. G., \& Bowler, P. A. (2001). Psychological restoration in nature as a positive motivation for ecological behavior. Environment and Behavior, 33(4), 590-607. https://doi.org/10.1177/00139160121973142

Kasser, T., \& Sheldon, K. M. (2002). What makes for a merry christmas? Journal of Happiness Studies, 3(4), 313-329. https://doi.org/ 10.1023/a:1021516410457

Kulshresta, U., \& Sen, C. (2006). Subjective well being in relation to emotional intelligence and locus of control among executives. Journal of the Indian Academy of Applied Psychology, 32(2), 93-98.

Leelanuithanit, O., Day, R., \& Walters, R. (1991). Investigating the relationship between marketing and overall satisfaction with life in a developing country. Journal of Macromarketing, 11(1), 3-23. https://doi.org/10.1177/027614679101100102

Lorenzoni, I., Nicholson-Cole, S., \& Whitmarsh, L. (2007). Barriers perceived to engaging with climate change among the UK public and their policy implications. Global Environmental Change, 17(3-4), 445-459. https://doi.org/10.1016/j.gloenvcha.2007.01.004

Marshall, G. N., Wortman, C. B., Kusulas, J. W., Hervig, L. K., \& Vickers, R. R. (1992). Distinguishing optimism from pessimism: Relations to fundamental dimensions of mood and personality. Journal of 
Personality and Social Psychology, 62(6), 1067-1074. https://doi.org/10.1037/0022-3514.62.6.1067

Maslow, A. H. (1943). A theory of human motivation. Psychological Review, 50(4), 370-396. https://doi.org/ 10.1037/h0054346

Maslow, A. H. (1962). Some basic propositions of a growth and self-actualization psychology. In A. W. Combs (Ed.). Perceiving, behaving, becoming: A new focus for education (pp. 34-49). Washington, DC: Association for Supervision and Curriculum Development.

Mayer, F. S., Frantz, C. M., Bruehlman-Senecal, E., \& Dolliver, K. (2009). Why is nature beneficial?: The role of connectedness to nature. Environment and Behavior, 41(5), 607-643. https://doi.org/10.1177/0013916508319745

Nelson, E. S., \& Mathias, K. E. (1995). The relationships among college students locus of control, learning styles and self-prediction of grades. Education Research and Perspectives, 22(2), 110-117.

Nielsen, L. (1987). Adolescent Psychology: A Contemporary View. New York: Holt, Rienhart, and Winton.

Nisbet, E. K., \& Zelenski, J. M. (2011). Underestimating nearby nature: Affective forecasting errors obscure the happy path to sustainability. Psychological Science, 22(9), 1101-1106. https://doi.org/10.1177/0956797611418527

Nisbet, E. K., Zelenski, J. M., \& Murphy, S. A. (2009). The nature relatedness scale. Environment and Behavior, 41(5), 715-740. https://doi.org/10.1177/0013916508318748

North, R. J., Holahan, C. J., Moos, R. H., \& Cronkite, R. C. (2008). Family support, family income, and happiness: A 10-year perspective. Journal of Family Psychology, 22(3), 475-483. https://doi.org/10.1037/0893-3200.22.3.475

Nunnally, J. C. (1978). Psychometric theory (2nd ed.). New York: McGraw-Hill.

Owusu-Ansah, F. E. (2008). Control perceptions and control appraisal: Relation to measures of subjective well-being. Ghana Medical Journal, 42(2), 61-67. https://doi.org/10.4314/gmj.v42i2.43597

Peterson, C. (2000). The future of optimism. American Psychologist, 55(1), 44-55. https://doi.org/10.1037/0003-066x.55.1.44

Post, S. G. (2005). Altruism, happiness, and health: It's good to be good. International Journal of Behavioral Medicine, 12(2), 66-77. https://doi.org/10.1207/s15327558ijbm1202_4

Schweizer, K., Beck-Seyffer, A., \& Schneider, R. (1999). cognitive bias of optimism and its influence on $\begin{array}{lllll}\text { psychological } \quad \text { well-being. } & \text { Psychological }\end{array}$ https://doi.org/10.2466/pr0.1999.84.2.627

Snyder, C. R., \& Lopez, S. J. (2002). Handbook of positive psychology. New York: Oxford University Press

Stolar, G. E., Macentee, M. I., \& Hill, P. (1992). Seniors'assessment of their health and life satisfaction: The case for contextual evaluation. The International Journal of Aging and Human Development, 35(4), 305-317. https://doi.org/10.2190/NEK7-5WGN-YEQU-N2CN

Strassle, C. G., McKee, E. A., \& Plant, D. D. (1999). Optimism as an indicator of psychological health: Using psychological assessment wisely. Journal of Personality Assessment, 72(2), 190-199. https://doi.org/10.1207/s15327752jp720203

Talbert, J. (2008). A new bottom line for progress. In L. Starke (Ed.), State of the world 2008: Innovations for a sustainable economy (pp. 18-31, 216-219). New York: W. W. Norton.

Von Heideken Wågert, P., Rönnmark, B., Rosendahl, E., Lundin-Olsson, L., Gustavsson, J. M. C., Nygren, B., . . . Gustafson, Y. (2005). Morale in the oldest old: the Umeå 85+ study. Age and Ageing, 34(3), 249-255. https://doi.org/10.1093/ageing/afi044

Wetherill, G. B., Duncombe, P., Kenward, M., Köllerström, J., Paul, S. R., \& Vowden, B. J. (1986). Regression analysis with applications. London: Chapman and Hall.

White, M. P., Alcock, I., Wheeler, B. W., \& Depledge, M. H. (2013). Would you be happier living in a greener urban area? A fixed-effects analysis of panel data. Psychological Science, 24(6), 920-928. https://doi.org/10.1177/0956797612464659

Xavier, F. M., Ferraz, M. P., Marc, N., Escosteguy, N. U., \& Moriguchi, E. H. (2003). Elderly people's definition of quality of life. Revista Brasileira de Psiquiatria, 25(1), 31-39. 
Xiao, J. J., \& Li, H. (2011). Sustainable consumption and life satisfaction. Social Indicators Research, 104(2), 323-329. https://doi.org/10.1007/s11205-010-9746-9

Appendix A. Dimensionality and Internal Consistency of Measures

\begin{tabular}{|c|c|}
\hline Determinants of Life Satisfaction & Factor Loading \\
\hline \multicolumn{2}{|l|}{ 1. Life in General } \\
\hline Delighted - Terrible Scale & 0.80 \\
\hline Faces Scale & 0.69 \\
\hline Satisfaction Scale & 0.80 \\
\hline Ladder Scale & 0.77 \\
\hline Variance Explained & $58.88 \%$ \\
\hline Coeff. Alpha & 0.76 \\
\hline \multicolumn{2}{|l|}{ 2. Optimism } \\
\hline When something bad happens you think it will disappear. & 0.72 \\
\hline You look at the good side of others and overlook the bad side. & 0.79 \\
\hline You often look on the bright side of your future. & 0.80 \\
\hline You are an optimist. & 0.83 \\
\hline Variance Explained & $61.51 \%$ \\
\hline Coeff. Alpha & 0.79 \\
\hline \multicolumn{2}{|l|}{ 3. Control } \\
\hline You can control your own fate. & 0.61 \\
\hline Any success or failure is up to you. & 0.75 \\
\hline You can manage surrounding matters. & 0.67 \\
\hline You are free to choose and act in your own way. & 0.70 \\
\hline The things that happen to you are a result of your own actions. & 0.70 \\
\hline You have the opportunity to change the things that you don't like. & 0.69 \\
\hline You are free to express your own opinion. & 0.74 \\
\hline The things that you choose are often based on your value and real interest. & 0.66 \\
\hline Variance Explained & $47.60 \%$ \\
\hline Coeff. Alpha & 0.84 \\
\hline \multicolumn{2}{|l|}{ 4. Family } \\
\hline Marriage & 0.74 \\
\hline Home-Life & 0.88 \\
\hline Children & 0.81 \\
\hline Housing & 0.84 \\
\hline Neighborhood & 0.77 \\
\hline Transportation & 0.62 \\
\hline Parents, Brothers, Sisters & 0.80 \\
\hline Variance Explained & $61.27 \%$ \\
\hline Coeff. Alpha & 0.89 \\
\hline \multicolumn{2}{|l|}{ 5. Personal Health } \\
\hline Wellness & 0.88 \\
\hline Stamina & 0.89 \\
\hline Mobility & 0.88 \\
\hline Appearance & 0.79 \\
\hline Variance Explained & $74.14 \%$ \\
\hline Coeff. Alpha & 0.88 \\
\hline \multicolumn{2}{|l|}{ 6. Material Possessions } \\
\hline House & 0.80 \\
\hline Furniture and Appliances & 0.79 \\
\hline Private Transportation & 0.79 \\
\hline
\end{tabular}




\section{Computers}

0.75

Mobile Phones

0.80

Clothing and Jewelry

0.83

Saving and Investment

Variance Explained

$60.18 \%$

Coeff. Alpha

\section{Altruism}

I have sympathy for others who are suffering.

I feel happy helping out others when they have problems.

I help others when I have the chance

Variance Explained

\section{Nature Lover}

If you are stressed, being with nature makes you feel relaxed.

If you worry, being close to nature will make you feel relieved.

You like to take forest trips.

You often feel happy when you can be with nature.

Nature has its own beauty.

Thinking about it, nature is a remarkable phenomenon in this world.

\section{Copyrights}

Copyright for this article is retained by the author(s), with first publication rights granted to the journal.

This is an open-access article distributed under the terms and conditions of the Creative Commons Attribution license (http://creativecommons.org/licenses/by/4.0/). 